\title{
I-20335-0025
}

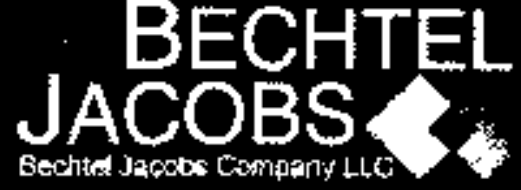

ENVIRONIJENTA RANLOENGNT

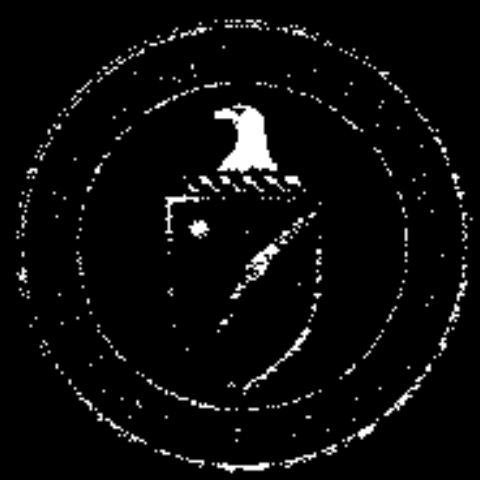

BECHTEL JACOAS COMPAMY LLC ACCEILERATED CLEANUP CONTRACT WHTH THE UNITED STATES U.S. DEPARTMEUT OF ENERGY
BJC/OR-2715, Rev. 2

\section{Environmental Management Waste Management Facility (EMWMF) Site-Speciflc Health and Safety Plan, Oak Ridge, Tennessee}

\section{CONTROLLED COPY}

CONTROLLED COPY\# -.

This document is approved for publsc release per review by

\begin{tabular}{|c|}
\hline BJC ETTP Classification \& \\
\hline
\end{tabular}


APPROVALS

Environmental Management Waste Management Facility (EMWMF)

Site-Specific Health and Safety Plan, Oak Ridge, Tennessee

BJC/OR-2715/R2

Prepared by:

Nick e C. C. $2 \lg$ on

EMWMF Site Safety and Health Representative

Bechtel Jacobs Company LLC

CTr. Play

Project Industrial Hygiene Lead

Bechtel Jacobs Company LLC

Review and Concurrence:

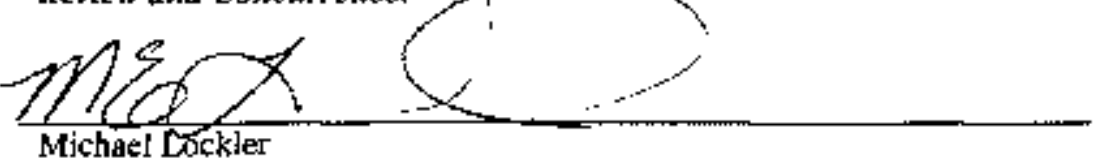

Field Services Area Manager

Bechtel Jacobs Company LLC

Angel D. Mc thee

A. D. MeGilp, WPH

Industrial Hygiene Manager

Bechtel Jacobs Company LLC

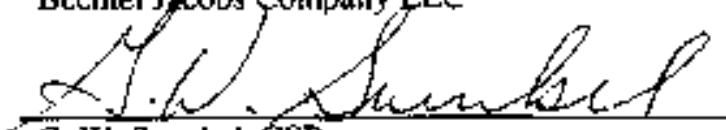

G. W. Suenkel, CSP

ACP ES\&H Supervisor and Safety Manager

Bechtel Jacobs Company L LC

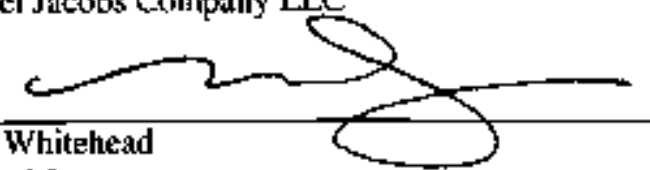

H. D. Whitehead

Project Manager

Bechtel Jacobs Company LLC

Approved by:

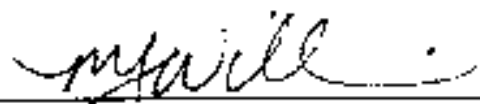

M. J. Williams

Manager of Projects

Bechtel Jacobs Company LLC
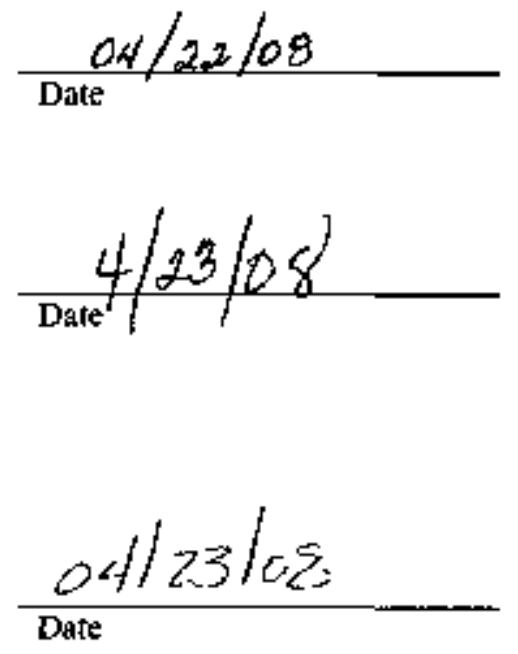

$\frac{04 / 24 / 08}{\text { Date }}$

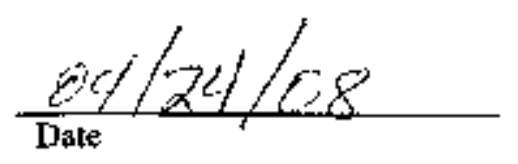

4123108

Date

$04 / 23 / 08$

Date 
BJC/OR-2715/R2

\section{Environmental Management Waste Management Facility (EMWMF) Site-Specific Health and Safety Plan, Oak Ridge, Tennessee}

Date Issued-April 2008

Prepared for the

U.S. Department of Energy

Office of Environmental Management

BECHTEL JACOBS COMPANY LIC

managing the

Ervironmental Managenent Activities at the

East Tennessee Technology Park

Y-I2 National Sccurity Complex Oak Ridge National Laboratory

under contract DE-AC05-980R22700

for the

U.S. DEPARTMENT OF ENERGY 


\section{APPROVALS}

Environmental Management Waste

Management Facility (EMWMF)

Site-Specific Health and Safety Plan,

Oak Ridge, Tennessee

BJC/OR-2715/R2

Prepared by:

N.C. Flynn

EMWMF Site Safety and Health Representalive

Bechtel Jacobs Company LLC

C.T.SLy

Project Industrial Hygiene Lead

Bechtel Jacobs Company LLC

Review and Concurrence:

Michael Lockier

Date

Field Services Area Manager

Bechtel Jacobs Company LLC

A. D. MะGill, MPH

Industrial Hygiene Manager

Bechtel Jacobs Compsiny LLC

G. W, Suenkel, CSP

Datte

ACP ES\&H Supervisor and Safety Manager

Bechtel Jacobs Company LLC

H. D. Whitehead

Date

Project Marnager

Bechte] Jacobs Company LLC

Approved by:

M. J. Witliams

Date

Manager of Projects

Bechtel Jacobs Company ELC 


\section{CONTENTS}

ACRONYMS viilix

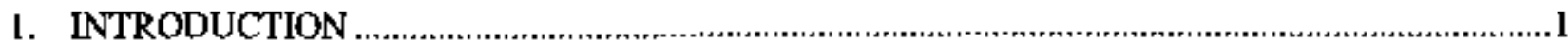

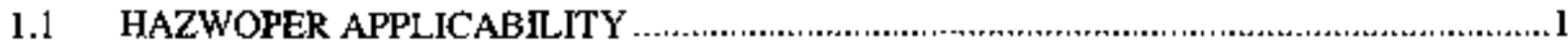

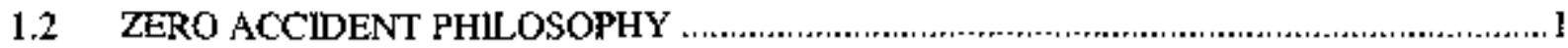

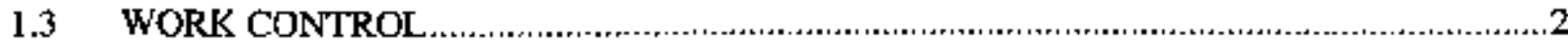

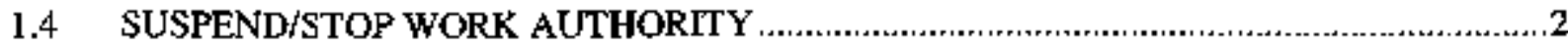

2. EMWMF OPERATIONS STRUCTURE

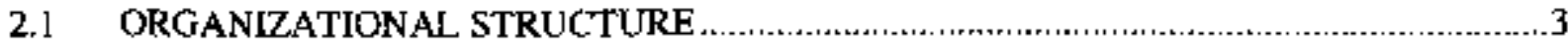

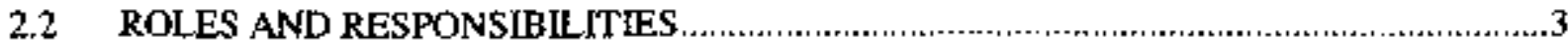

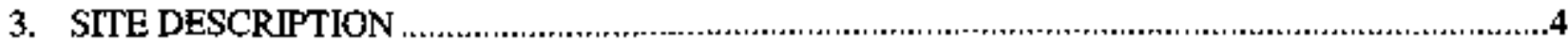

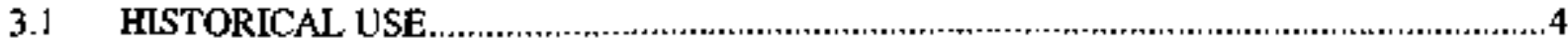

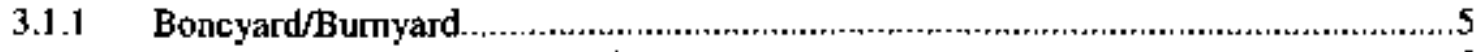

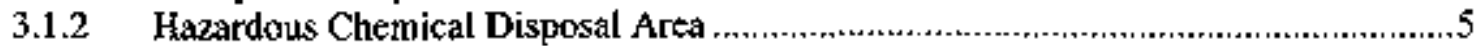

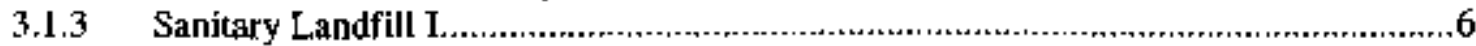

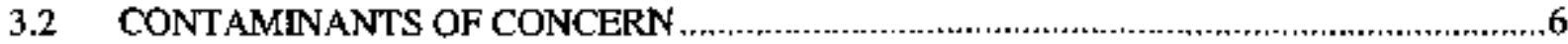

4. SITE ACCESS REQUIREMENTS

4.1 ACCESS ORIENTATION

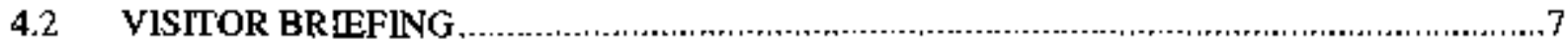

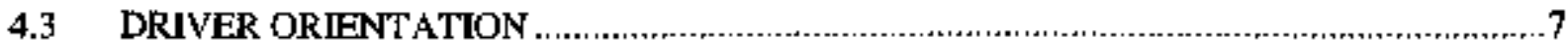

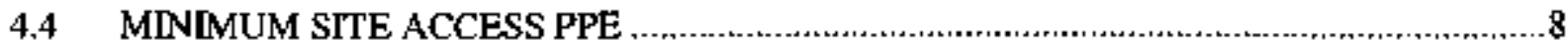

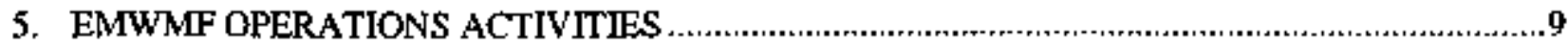

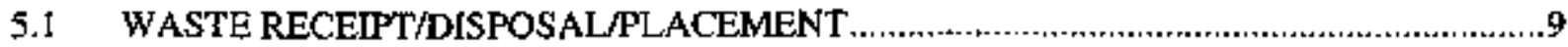

5.2 LEACHATE AND CONT ACT WATER MANAGEMENT ….........................................

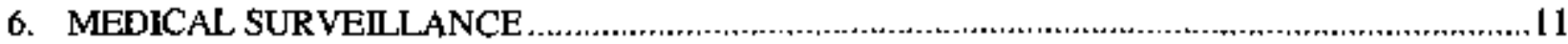

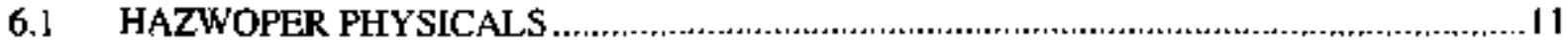

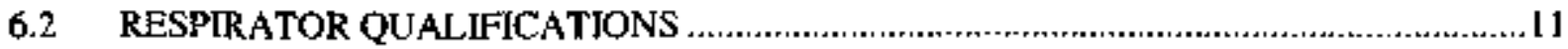

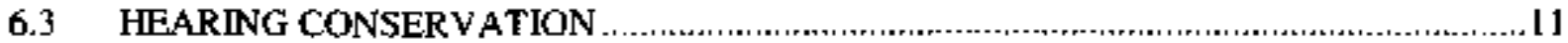

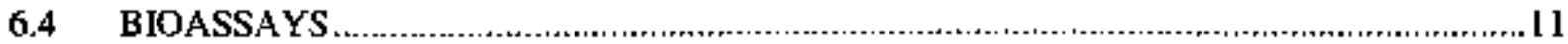

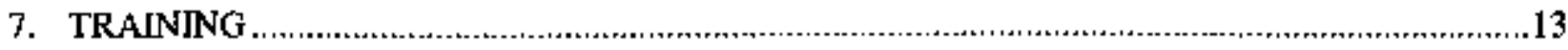

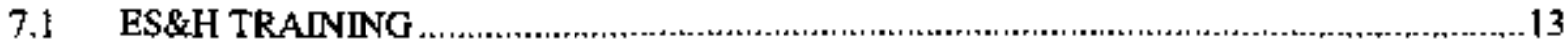

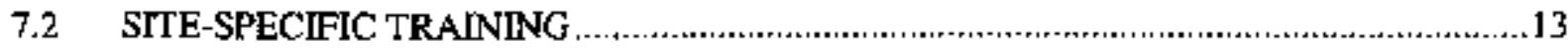

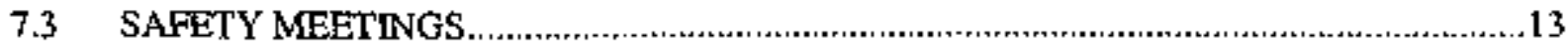

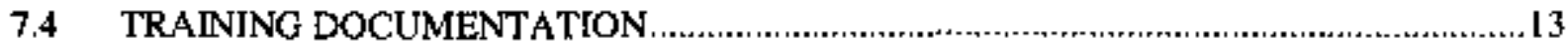

8. SITE-SPECIFIC PERSONAL PROTECTIVE EQUIPMENT ,............................................14

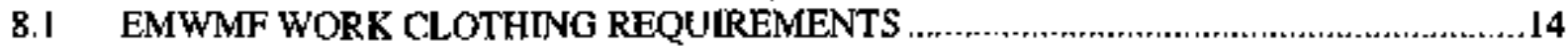

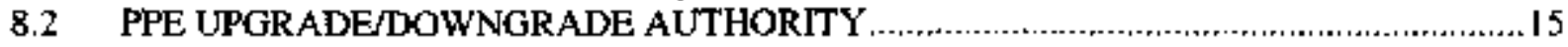

8.3 PPE DONNING/DOFFING GUIDELINES ............................................................ 15

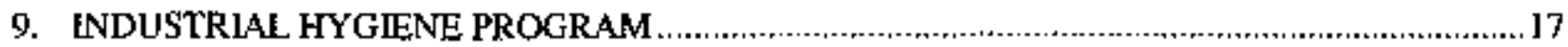

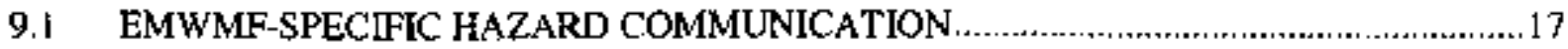

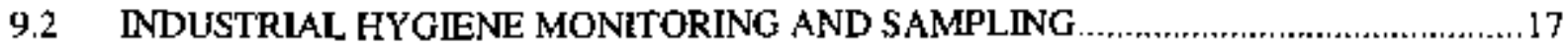


9.2.1 Monitoring and Sampling Methods and Instrumentation .................................17

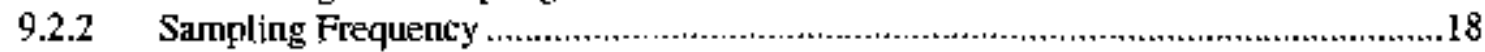

9.3 CHEMICAL HAZARDS/CONTAMINANTS ...................................................... I 8

9.3.1 Silica, Crystalline (Quartz and Crystabalite) .............................................. I 8

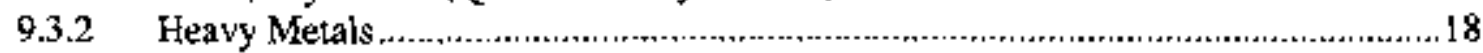

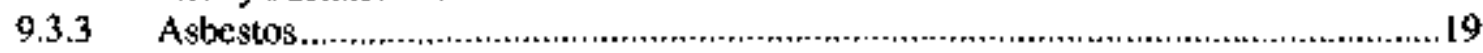

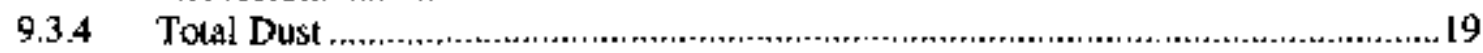

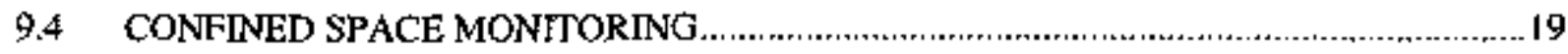

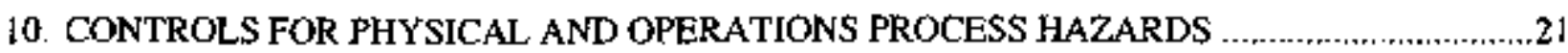

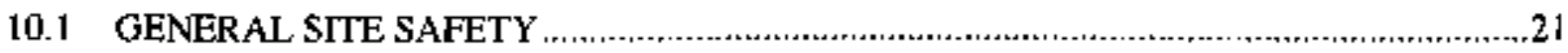

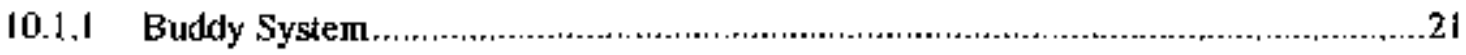

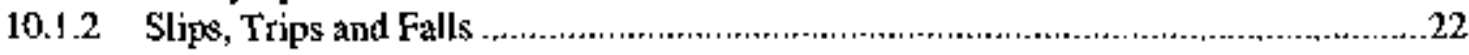

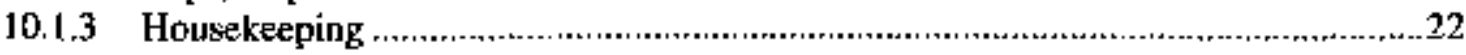

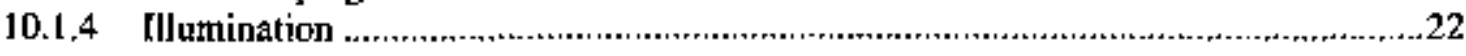

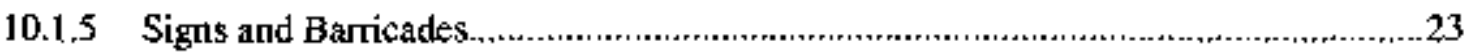

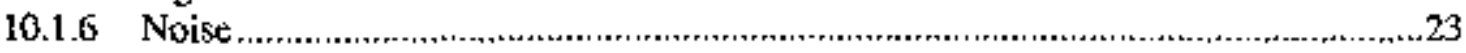

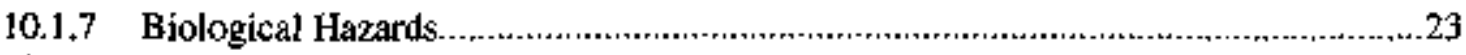

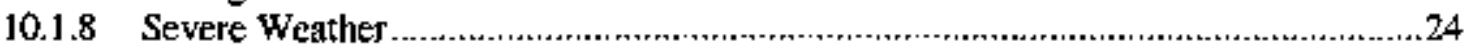

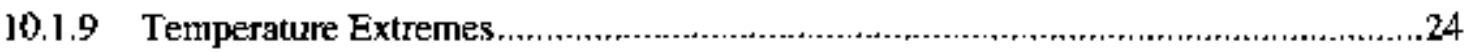

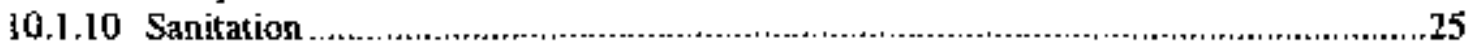

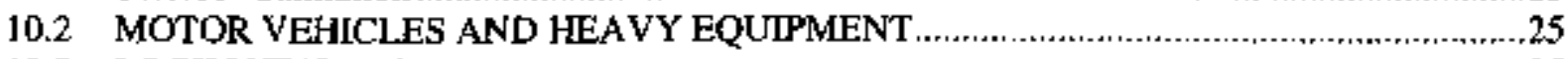

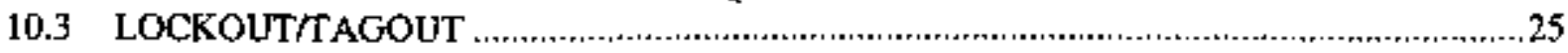

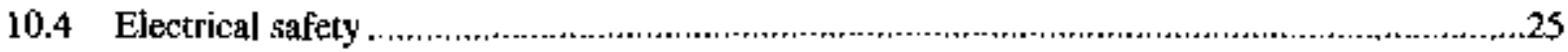

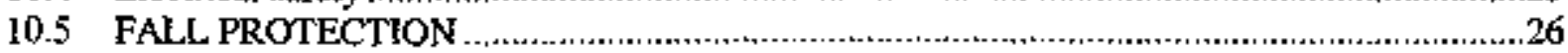

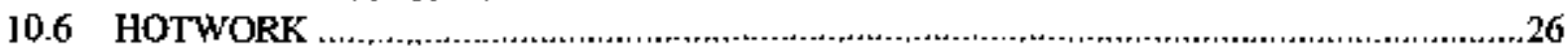

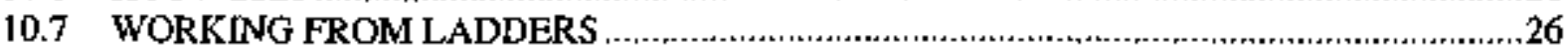

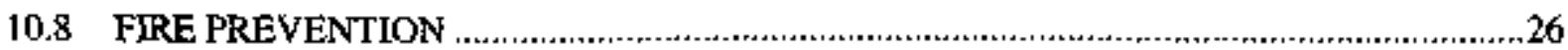

10.9 TOOL SAFETY

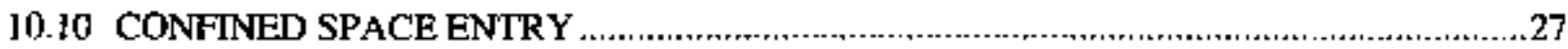

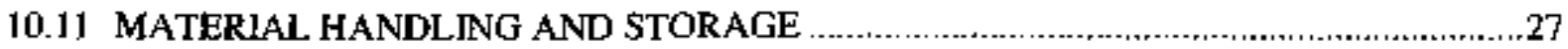

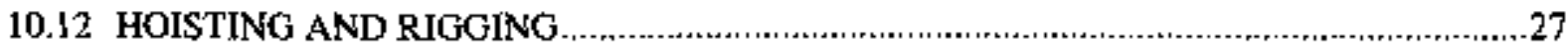

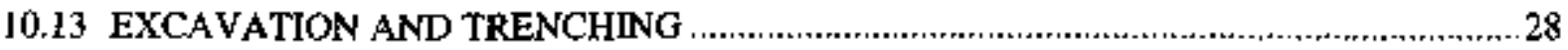

10.14 EMERGENCY EYE WASH AND PERSONNEL DECONTAMINATION SHOWER ........28

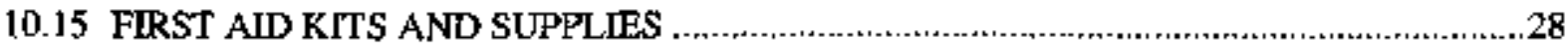

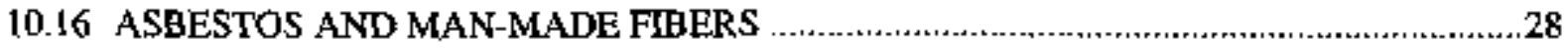

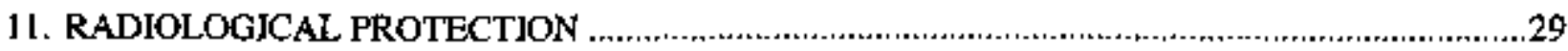

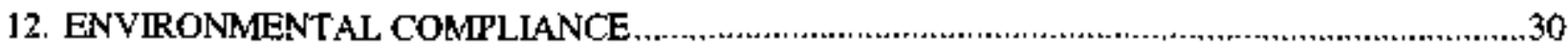

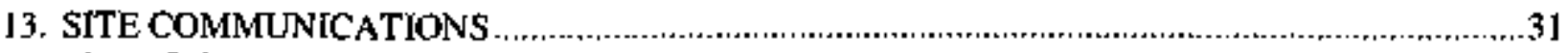

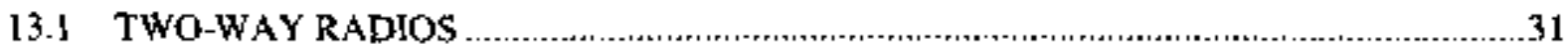

13.2 DEPARTMENT OF ENERGY (DOE) TELEPHONE SYSTEM $\ldots \ldots \ldots \ldots \ldots \ldots \ldots \ldots \ldots \ldots \ldots \ldots \ldots \ldots$

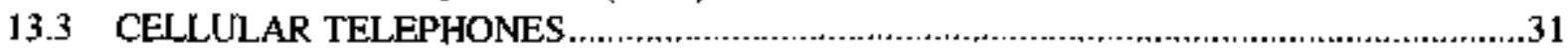

14. NOTIFICATION AND REPORTING ......................................................................... 32

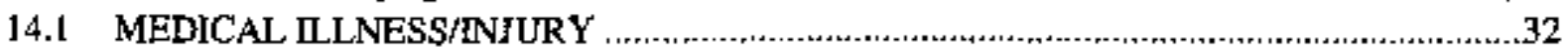

14.2 ACCIDENT/INCIDENT REPORTING AND RECORDKEEPING ..............................33

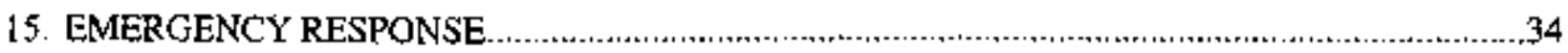

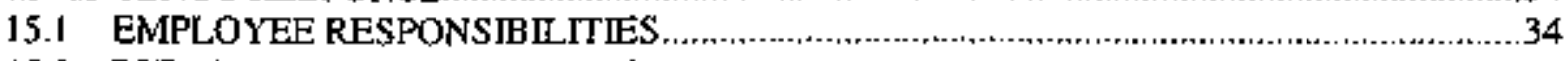

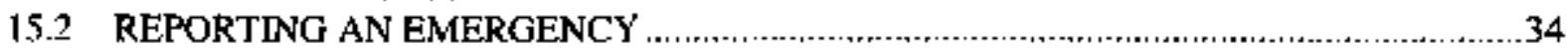


15.3 EVACUATION ROUTES

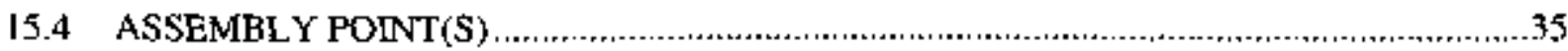

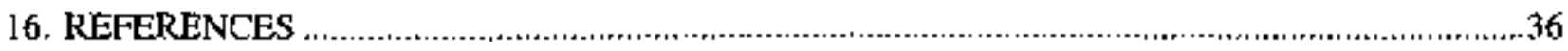




\section{ACRONYMS}

ACGLH

$A C M$

AHA

ANSI

BCBG

BJC

BY/BY

CERCLA

CFR

CPR

CRZ

dBA

DOE

EC\&P

ECP

EMWMF

EPA

ERT

ES\&H

ETTP

FR

FRE

HASP

HAZCOM

HAZWOPER

HBV

HCDA

IDLH

[H

ISMS

LCS

LEARN

LEL

LGWT

LOTO

MSDS

NEC

NFPA

NIOSH

NRR

NT

OLF

ORNL

ORR

OSHA

PEL,

POD

PPE
American Conference of Govemmental Lnduscial Hygienists

Asbestos containing matstial

activity hazard assessment

American National Standards Institute

Bear Creek Burial Grounds

Bechtel Jacobs Company LLC

Boneyard/Burnyard

Comprehensive Environmental Response, Compensation, and Liabilities Act

Code of Federal Regulations

cardiopulmonary resuscitation

Contamination reduction zone

Decibels on the A-weighted scale

U.S. Department of Energy

Environmental Compliance and Protection

Environmental Compliance Plan

Environmental Maragement Waste Management Facility

U.S. Environmental Protection Agency

Emergency Response Team

Environmental, Safety and Health

East Tenncssee Tecbnology Patk

Flame resistant

Field Radiological Engineer

Health and Safety Plan

Hazard Commurication

Hazardous Waste Operations and Emergency Response

Hepatitis-B vaccination

Hazardous Chemical Disposal Area

immediately dangerous to life or health

industrial hygiene

Integrated Safety Manigement System

Leachate Collection System

Local Educative Administrative Requirements Network

Lower Explosive Leve]

Liquids and Gaseous Waste Treatment

Lockout/Tagout

Material Safety Data Sheet

National Electric Codes

National Fine Protection Association

National Institute of Occupational Safety and Health

Noise Reduction Rating

North Tributary

Oil Landfarm

Oak Ridge National Laboratory

Oak Ridge Reservation

Occupational Safety and Health Adtninistration

Permissible Exposute Limit

plan of the day

personal protective equipment 
PSS

PWT

QA

RCRA

RCT

$\mathrm{R}$ ]

RWP

SPO

SSHR

TLD

TIVE

TSCA

TWA

UL

WBGT
Plant Shift Superintendent/Park Shift Superintendent

Park Worker Training

Quality Assurance

Resource Conservation and Recovery Act

Radiological Control Techrician

Remedial lnvestigation

radtation work permit

Security Police Officer

Site Safety and Health Representative

themoluminescent dosimeter

Theshold Limit Value

Toxic Substances Control Act of 1976

timte-weighted average

Underwriters Laboratory

wet bulb globe temperature 


\section{INTRODUCTION}

The Bechtel Jacobs Company LLC (BJC) policy is to provide a safe and healthy workplace for all employees and subcontractors. The implementation of this policy requires that operations of the Environmental Management Waste Management Facility (EMWMF), located one-half mile west of the U.S. Department of Energy (DOE) Y-12 National Security Complex, be guided by an overall plan and consistent proactive approach to environment, safety and health (ES\&H) issues.

The BEC governing document for worker safety and health, BJC/OR-1745, worker Safety and Health Program, describes the key elements of the BJC Safety and Industrial Hygiene (IH) programs, which includes the requirement for development and implementation of a site-specific Health and Safety Plan (HASP) where requited by regulation (refer also to BJC-EH-1012, Development and Approval of Safety and Health Plans). BJClOR-1745, Worker Safety and Health Program, implements the requirements for worker protection contained in Title 10 Cade of Federal Regulations (CFR) Patt 851. The EMWMF site-specific HASP requirements identifies safe operating procedures, work controls, personal protective equipment, roles and responsibilities, potential site hazards and control meastures, site access requirements, frequency and types of monitoring, site work areas. decontamination procedures, and outlines emergency response actions. This HASP will be available on site for use by all workers, management and supervisors, oversight personnel and visitors. All EMWMF assigned personnel will be briefed on the contents of this HASP and will be requirad to follow the procedures and protocols as specified.

The policies and procedures referenced in this HASP apply to all EMWMF operations activitics. In addition the HASP establishes ES\&H criteria for the day-to-day activities to prevent or minimize any adverse effect on the environment and personnel safety and health and to meet standards that define acceptable waste management practices. The HASP is written to make use of past experience and best management practices to eliminate or minimize hazards to workers or the environment from events such as fires, falls, mechanical bazards, or any unplanned release to the environment.

\subsection{HAZWOPER APPLICABILITY}

Operation of the EMWMF has been determined to be within the scope of OSHA 29 CFR 19]0.120 and 29 CFR 1926.65, Hazardous Waste Operations and Emergency Response (HAZWOPER). As a disposal facility compliant with by $40 C F R$ Parts 264 and 265 pursuant to the Resource Conservation and Recovery Act (RCRA); or by agencics under agreentent with U.S. Environmental Protection Agency (EPA) to implement RCRA regulations.

\subsection{ZERO ACCIDENT PHILOSOPHY}

BJC is dedicated to the concept that all accidents, injuries, and incidents are preventable, and is comminted to integrating safety into all aspects of work, work plarning, and execution. This integration is accomplished through the Integrated Safety Management System (ISMS). Personnel committed to safety in the workplace are key to the success of ISMS. Worker involvement is to be solicited from the onset of each task. Lessons leamed and past tasks will be reviewed to add to the efficiency of the effort. ISMS principles shall be used to ensure the performance of quality work, completed safely and in a timely manner. BJC-GM-1400, Integrated Safaty Management System Description, shall be used to implement ISMS duritig EMWMF operations activities. 


\subsection{WOKK CONTROL}

EMWMF operations activities are performed in accordance with BJC-FS-1001, Work Control Process, or the development of work packages. Each work package must contain task-specific job instructions or operating procedures with sufficiently detailed information to provide workers with a clear understanding of the tasks, materials, equipment, potential hazards and controls to mitigate identified hazards. BJC-EH-2010, Hazard Assessment, will be in conjunction with operating procedures or in the development of work package job instructions to ensure potential hazards associated with work activities are identified and appropriate control measures are included to mitigate those hazards. Worker tnvolvement is a key element in the hazard assessment process and development of work control documents.

\subsection{SUSPEND/STOP WORK AUTHORITY}

All workers have the responsibility and authority to Suspend or Stop Work when actions or operations pose a danger to personnel or the environment, when unsafe condisions are observed, or they question the safety of the work to be performed. Workers shall have the right atyd obligation to report unsafe conditions and to Suspend or Stop Work without fear of reprisal. 


\section{EMWMF OPERATIONS STRUCTURE}

\subsection{ORGANIZATIONAL STRUCTURE}

Roles and responsibilities for key personncl for EMWMF operations are described in BJC/OR-2713. EMWMF Operations Plan. An organization chart is also provided in that Plan. BJC EMWMF operations personnel designated as key contacts for emergency response activitics are identified in BJC/OR-2714. EMWMF Emergency Response and Contingency Plan. Among the key contact personnel are the ETTP and Y-I 2 Plant Shift Superintendent (PSS).

\subsection{ROLES AND RESPONSFILITIES}

Cleasly defined roles and tesponsibilities are a significant element in the successful performance of all EMWMF operations activities. BJC/OR-27 13, EMWMF Operations Plan, contains detailed descriptions of the roles and responsibilities for the BJC EMWMF operations organization.

All personnel have a clear undersianding of their roles, and have the following responsibilities:

- Safety for themselves and others.

- Reporting unsafe conditions and suspend or stop work until condition is corrected.

- Reporting actual or potential environmental impacts.

- Performing work in a safe manter.

- Performing only the tasks for which they are trained.

- Notifying the Site Safety and Health Representative (SSHR) when taking prescription or nonprescription medication that might cause drowsiness, alxiety or other side effects that could interfere with the safe performance of work.

- Immediately reporting all injuries, no matter how minor, to the SSHR and line supervision.

- Practicing good housekeeping by keeping work areas neat, clean, and orderly. 


\section{SITE DESCRIPTION}

The EMWMF is located in East Bear Creek Valley, between Bear Creek North Tributaries NT-3 and NT-5, near Oak Ridge, Tennessec. It is located approximately one mile downstream of the headwaters of Bear Creek, which originates within the westem portion of the Y-12 National Security Complex. The EMWMF is located well above the 100 -year floodplain.

The EMWMF is a multi-celled, above-grade disposal facility authorized under the Comprehensive Environmental Response, Compensation, and Liability Act (CERCLA) of 1980. It is used for the disposal of low-level tadioactive waste, hazardous waste as defined under the RCRA, hazardous waste as defined under the Toxic Substances Control Act (TSCA) of 1976, and mixed waste consisting of combinations of these wasle types. Such wastes are generated duting waste management/site remediation activities on the Oak Ridge Reservation (ORR) and facilities located off the ORR that are associated with past ORR activities. Additionally, the EMWMF is capable of accepting classified wastes.

Construction of the EMWMF was completed in early May 2002. Following acceptance of the Construction Completion Report by the EPA and the Tennessee Department of Environment and Conservation, the EMWMF began operations on May 28, 2002.

The EMWMF utilizes distinctly separate facilities directly involved in the waste disposal operations and include the following: disposal cells, a leachate transfer and storage system and contact water ponds. Waste shipments ane transported in vehicles such as dump trucks, roll-off container trucks or flatbed trailers. It is then either dumped into the disposal cells from a dump ramp or direct dumped/placed onto the floor of the disposal cell. Waste disposed from domp ramps is pushed to a final disposal location with heavy equipment. Waste that is direct dumped/placed may be pushed but primarily is placed at the location where it is offloaded.

Leachate, precipitation that percolates through the disposed waste, flows by gravity to a lift station where it is pumped to one of five 30,000 -gallon storage tanks. After sampling, leachale is transfened from the tanks into 4,500-gallon tanker trucks for transport to the Oak Ridge National Laboratory (ORNL) Liquids and Gaseous Waste Treatment (LGWT) facility.

Contact water, precipitation that falls onto waste but does not percolate through the waste ${ }_{+}$is pumped to one of four 450,000 -gallon contact water ponds. Contact water is sampled for a list of constituents of concem and if below pre-established release criteria is pumped to the sediment basin with eventual discharge to Bear Creek. Contact water not meeting the release criteria is loaded into tankers and transported to ORNL LGWT facility.

Other ancillary support facilities such as office trailers and a craft change/decontamination trailer are aiso located at the site.

\subsection{HISTORICAL USE}

The Y-12 Plant was built by the U.S. Army Corps of Engineers in 1943 as part of the Manhattan Project. Liquid wastes generated by the B\&W Y-12 consisted primarily of nitric acit, nitrate waste, pickling and plating waste, and miscellaneous ljquid wastes associated with routine cleanup operations (e.g., mop water). Other wastes included solvents, dilute acid, machine coolants, caustic solutions, and acids with a $\mathrm{pH}$ of $<2.0$. Solid wastes, including uranium metal, were generated by normal plant operations. Wastes were disposed of at various sites in Bear Creek Valley, which is estimated to have received $374,000 \mathrm{~m}^{3}$ $\left(489,000 \mathrm{yd}^{3}\right)$ (volume estimale does not include SLl and the OLF) of urartium, uranium-containing 
material, and sludge [DOE 1997a). The S-3 Ponds, BY/BY, OLF + SL1, and BCBG are considered the primary contaminant sources in Bear Creek Valley. In addition, a number of smaller sites in the Bear Creek watershed are either identified as solid waste management units or listed in the Federal Facility Agreement, such as the Bear Creek Road Debris Burial Area and the Creekside Debris Burial Atea. Additjonal sites such as the Rust Spoil Area, Spoil Area L, and SY-200 Yard have been used for waste disposal or storage. The latter two siles were addressed separately under Bear Creek Valley Operable Unit 2. Detailcd descriptions of disposal histories and operations can be found in Tables 3.2 and 3.3 in the Remedial hnvestigation ( $R \Gamma$ ).

\subsubsection{Boneyard/Burnyard}

BY/BY, located west of the S-3 Ponds and adjacent to OLF, consists of three sites: the Boneyard, the Bumyatd, and HCDA. BY/BY was one of the first areas established in Bear Creek Valley for the disposal of waste generated at the Y-12 facility. BY/BY is estimated to have received $41,000 \mathrm{~m}^{3}(54,000 \mathrm{yd})$ of uranium-containing materia $\mathrm{I}_{+}$which represents $1 \mathrm{l}$ percent volume of the uranium-containing material disposed of in Bear Creek Valley (DOE 1997a).

The Boneyard, a series of unlined earthen trenches located east of the OLF, was an active waste-disposal site from 1943 to 1970 . Wastes have been characterized as ranging from ignitable and radioactive to inert. They included organics, metals, debris, acids, and beryllium. The total quantity of material is unknown. Magnesium chips were disposed of in the southwestern corner of the BY/BY by placing them in burn pans in unlined earthen trenches and using ignitable solvents to initiate buming. The residue remaining in the trenches was covered with soil and compacted until the trenches were filled. The trenches were then covered with topsoil and seeded with grass. The remaining land in the BY/BY was used to dispose of construction spoil material such as concrete and rebar. Observations made during field activities indicate the presence of contaminated debris at the surface (DOE 1997a).

The Bumyard functioned as an active waste site from 1943 to 1968 . The site received approximately 268 $\mathrm{m}^{3}$ of sanitary rofuse from plant operations, including solids, liquids, and sludges. Waste materials may have contained empty pesticide containers, metal shavings, solvents, oils, and laboratory chemicals. Wastes were placed in unlined earthen trenches and burned. Oils and other flammable liquids (possibly transformer oujs containing PCBs) were used to start and sustain combustion. When filled, the trenches were covered with soil. According to avaiłable information, no collection or treatment systems other than buming were uscd on-site.

Note: BY/BY has been remediated and the majority of the waste was disposed at the EMWMF.

\subsubsection{Hazardous Chemical Disposal Area}

The Hazardous Chemical Disposal Area (HCDA) received solid, liquid, and gaseous waste materials from 1975 to $198 \mathrm{~L}$. According to estimates, the site received $<3.8 \mathrm{~m}^{3}$ of waste annually. The material was characterized as ignitable, reactive, corrasive, toxic, hightly flammable, or, in some instances, inert. Generally, the HCDA received wastes that posed safety bazards within the Y-12 facility. The material canie from gas cylinders with leaking or damaged valves and laboratory chenicals considered to be reactive or explosive. The labotatory chemicals included acids, bases, organics, water-reactive compounds, and explosive compounds such as picric acid, benzoyl peroxide, and ether. Bottles of chemicals were broken under water spray in a concrete vessel that was open to the atmosphere. After the chemical reaction occurred, the effluent was discharged into a small, unlined surface impoundment and aliowed to percolate through the soil. The chemical residue remaining in the concrete vessel was removed periodically and transported to the BCBG. In 1989, the entire HCDA, including the contaminated soil. was capped with a RCRA-iype multi-layer cap. 


\subsubsection{Sanitary Landfitl I}

Santitary Landfill is approx imatcly $1.3 \mathrm{~km}(0.8 \mathrm{mile})$ west of the B\&W Y-12 facility, just north of Bear Creek and immediately south of the OLF. It was used between 1968 and 1980 for the disposal of combustible and decomposable solid waste. The landfill received materials such as paper, cardboard, plastics, rubber, wood, bnush, animal bedding, organic garbage, textile products, and asphalt roofing materials. Although administrative controls were used to exclude the disposal of toxic chemicals and other contaminated materials, it is possible that some of these materials were disposed of in the landfill.

\subsection{CONTAMINANTS OF CONCERN}

Contaminants currently disposed of in the active waste cells include low levels of radionuclides such as: Uranium-233/234/235/236/238; Cesium-137; Neptunium-237; Am-241; thorium-228/230/232; radium-226/228; Plutonium-238/239; Cm-244; Tc-99 and Sr-90. In addition, low concentrations of volatile organics, semi-volatile organics, metals, pesticides, PCBs, and asbestos containing material (ACM) are present in disposed waste. Waste disposed of to date has included soils, concrete debris, serap metal, equipment and piping, and construction debris.

Waste characterization data for approved waste lots that will be disposed at the EMWMF are provided by the generating remedial action projects. Dala is provided for radiological and non-radiological contaminazts. 


\section{SITE ACCESS REQUIREMENTS}

EMWMF includes two access areas: the Limited Area and Properly Protection Area. The Property Protection Area includes all area outside the Limited Area and the administrative office trailer area where visitors report. The Limited Area consists of the area within the security fence that surrounds the disposal cells. Securtity Police Officers (SPOs) control access to the Limited Area.

Access to the EMWMF Ptoperty Protection Area and Limited Area requires a DOE photo badge or a DOE visitor badge. Access to the Limited Area requires the completion, including name, badge number, badge type (e.g., KA), serial number, and clearance level, of an EMWMF Limited Area Access form. The form must be submitted to BJC at least 24-hours prior to planned access into the Limited Area.

Uncleared United States citizens may yisit the EMWMF provided that the need for the visit is justified. BJC must transmit a visitor request form to the ETTP Visitor Control Center for uncleared visitors who to not have a DOE photo or visitor badge. A 24-hours advance notice must be provided to BJC to request this site access. The visitors are required to obtain a Visitor Badge from the ETTP Visitor Control Office prior to entering the EMWMF site. In addition, visitors are required to provide photo identification and sigt the EMWMF Visitor Roster. Uncleared visitors will not be allowed to access the EMWMF Limited Area when classified waste disposal operations are heing conducted, and they must be escorted during non-ciassified waste disposal operations.

All personnel and visitors are required to record their presence onsite by signing an EMWMF roster. The following sections discuss required training and the minismum personal protective equipment (PPE) required for site access.

\subsection{ACCESS ORIENTATION}

Personnel assigned to the EMWMF, DOE oversight, and others requiring unrestricted access to perform hands-on work at the site stall receive EMWMF Site Access Orientation. The orientation includes, but is not limited to, descriptions of EMWMF waste receipt and disposal operations, site hazads and controls to mitigate the hazards, PPE requirements, signs and barricades, access restrictions, security requirements. site speed limits, emergency response, evacuation and accountability.

\subsection{VISITOR BRIEFING}

Visitors going onsite shall recejve a Visitor Briefing. This briefing is a condensed Site Access Orientationbut does address operations for the day of the visit, hazards and controls for visitor's activities, e.g., site tour, PPE, signs and postings, access restrictions, and security requirements.

Visitors are escorted at all times by a trained employee. Minimum training for visitor escorts is Park Worker Training/General Enployee Training, Escort Training, and Site Access Orientation.

\subsection{DRIVER ORIENTATION}

Drivers of waste transport vehicles are provided an EMWMF orientation briefing prior to making initial waste shipment deliveries at EMWMF. This briefing addresses site hazards and controls, traffic rules, PPE requirements, site layout and access to the disposal cell area (Limited Area). 


\subsection{MINIMUM SITE ACCESS PPE}

Appropriate work apparel, as described in BJC-EH-2000, General Safery Requirentents, shall be wom by EMMWF employees and visitors. In addition, minimum PPE requirements beyond the office and parking lot areas include sturdy leather work shoes, high visibility vest, safety glasses, and hard hats (where overhead hazards are present). Sandals and open-toed shoes in the gravel parking area by the office and support trailers are discouraged due to the potential for slips, trips and falls. 


\section{EMWMF OPERATIONS ACTIVITIES}

Waste shipments to the EMWMF are primarily wastes generated during waste management/site remediation activities on the ORR and facilities located off the ORR that are associated with past ORR activities.

\subsection{WASTE RECEIPT/DISPOSAL/PLACEMENT}

Types of waste shipped to the EMWMF will include, but are not limited to, soil, soft waste, concrete and building debris, bulk items, organic materials, transite pallets and ACM. Waste will be transported via dump trucks, flat bed trailets, roll-off containers and other types of transport vehicles.

Waste transported from the ETTP will travel via the Haul Road, which is a road from ETTP to the EMWMF approximately 8 miles in length specifically constructed to keep waste shipments off public roads, or via Bear Creek Road. Upon arrival at the EMWMF waste transport vehicles entering the sitc from Bear Creck Road will cross a weigh scale and proceed to a checkpoint for an incoming radiological survey performed by BJC's radiological subcontractor personnel, and shipments arriving via the Hau] Road receive incoming radiological surveys on a random basis. After the incoming survey transport vehicles proceed to the disposal cell area (Limited Area) and are directed to the appropriate dumping area to dispose of the waste shipment. EMWMF operations personnel (laborers) verify information on the shipping papers prior to directing the driver to the dump ramp or direct dump location. Waste transport vehicles receive an outgoing radiological survey before being released to retum to the waste generating project. Disposed waste is either pushed to final placement in the active disposal cell, ditect placed at a final location or if waste contains asbestos it is covered with clean fill or a fixative applied.

During waste receipt, disposal and placement personnel are exposed to physical and biological hazards such as slips/trips/falls, pinch points, ergonomic concerns (lifting and pushing), sharp edges, vehicle and heavy equipment operation, excessive noise, temperature extremes, and dust as well as potential exposure to radioactive and chemical contamination. Engineering controls such as dust suppression and appropriate PPE are among the controls utilized to mitigate these hazards.

\subsection{LEACHATE AND CONTACT WATER MANAGEMENT}

Leachate, precipitation that falls onto and percolates through the waste, is collected in the Leachate Collection System (LCS) and gravity flows to the Leachate Collection Tank where it is then pumped to the leachate storage tanks. The leachate storage tanks are sampled after every 140,000 gallons of jeachatc collected and contained in the tanks. The samples are analyzed for an established list of contaminants of concem, which is updated hased on radiological and chemical constituents in the disposed waste, and then is pumped to transport tankers for offsite treaiment and disposal.

Contact water, precipitation that falls onto but does not percolate through the waste, is pumped from catchments in the disposal cells to four contact water holding ponds. The contact water is sampled and analyzed for an established list of contaminants of concem that is updated based on radiological and chemical constituents identifled in disposed waste lots. Contact water may be released from the contact water ponds directly to the site sedimentation basin if analytical results from sampling indicate all results to be within acceptable limits. If analytical results exceed acceptable limits then the contact water must be pumped to transport tankers and shipped for offsite treatment and disposal. 
Management of leachate and contact water typically involves moving gasoline powered generators, hoses. pumps, opening and closing valves, and climbing fixed and/or portable straight ladders to operate transfer system components for loading transport tankers. Personnel are exposed to slips/trips/falls, pinch points, ergonomics related to lifting and pulling as well as the potential for radioactive and chemical contamination. Enginecring controls, c.g., tying off of ladders and approptiate PPE are some of the controls used to address the hazards associaled with the perfomance of these tasks. 


\section{MEDICAL SURVEILANCE}

\subsection{HAZWOPER PHYSICALS}

Compliance with the requirements of $29 C F R \quad 1910.120$ and $29 C F R$ 1926.65 ensures that EMWMF Operations personmel are medically qualified to perform their assigned tasks and to wear required PPE including respiratory protection. The Site Safely and Health Representative (SSHR) may recommend personnel to the Project Industrial Hygiene (IH) Lead, and assist in the detennination, by the Project $\mathrm{WH}$ Lead, of which workers meet the criteria. Refer also to BJC/OR-1745, Worker Safety and Healkh Program, for requirements associated with occupalional medicine for BJC self-performed and subcontractors at all tiers. HAZWOPER physicals are required for workers who:

- May be exposed to hazardous substances at or above the permissible exposure limit (PEL) for 30 days per year.

- Must wear a respirator for hazardous waste operations.

- Exhibit adverse health effects due to potential overexposures from hazardous substances.

- May respond (as part of job responsibilities) to hazardous spilis or releases.

The SSHR will verify compliance with applicable medical gualification requirements for EMWMF.

\subsection{RESPIRATOR QUALIFICATIONS}

EMWMF personnel required to wear respirators during the course of waste disposal operations shall participate in a medical surveillance program that meeting requirements established in BJC-EH-5151, Respiratory Protection Program. Only personnel who are medically qualificd to wear a respirator will be assigned to tasks requiring use of respiratory protection.

\subsection{HEARING CONSERVATION}

EMWMF operations personnel shall comply with requirements established in BJC-EH-5121, Occupational Noise Exposure and Hearing Conservation Program. Compliance will include enployee participation in the Heating Conservation Program that will provide for antulal audiometric testing of designated employees. Hearing protection is required to be wom for all work in areas where noise levels. are at or exceed 85-dBA. Posting requirements for noise hazards shall be instituted for those areas routinely exhibiting noise levels at or above 85-dBA. EMWMF operations activities where equipment noise levels may exceed 85-dBA include gas- or clectrically-powered hand tools and equipment, generators, heavy equipment operation used for waste disposal and placement. Incoming machincry and equipment will be reviewed by the Project Industrial Hygiene Lead to Actermint if a noise level evaluation will be needed.

\subsection{BJOASSAYS}

The necessity and frequency of internal radiation monitoring (collection of bioassays) will be determined by the BJC Field Radiological Engineer Lead (FRE). Personnel, (BIC and subcontractor lif applicable]) are responsible for submitting bioassay samples as required by BJC. Failure of any BJC and/or 
subcontractor personnel to comply with bioassay requirements will result in restricting that individual that is more than 28 days delinquent from radiological areas and tadjological buffer areas until such time that the bioassay requirements are completed and the restiction has been lifted by Dosimetry. 


\section{TRAINING}

\subsection{ES\&H TRAINING}

Personnel assigned and working at EMWMF shall possess the experience, knowledge and skillis necessary to safely and effectively fulfill their duties. A training matrix shall be maintained to ensure employees have completed all training necessary for their assigned work. All personnel must successfully complete the approptiate safety and health training in accordance with regulatory, DOE and site-specific requircments. Each individual will be responsible for executing work safely and in a manner consistent with the training provided.

\subsection{SITE-SPECIFIC TRAINING}

A training matrix specifying site-specific training requirements for EMWMF Operations personnel has been developed. The matrix is used to identify training requirements for each position in the EMWMF operations organization. The Site Safety and Health Representative (SSHR), Cell Operations Superintendent, and Maintenance and Facilities Superintendent are responsible tor ensuring that all personel, BJC and subcontractor, performing work at the EMWMF have completed required training prior to work being performed. Training requirements for subeontractor personnel performing work as EMWMF are described in subcontract requirements.

The BJC-issued Site Access Card shatl be used to document training and medical qualifications for the following:

- Park Worker Training/General Employee

- Radiation Worker II

- HAZWOPER (basic 24- or 40-hour and current 8-hr fefresher)

- Respirator training and fit test

- Bioassay

- Nuclear Críticality safety

\subsection{SAFETY MEETINGS}

All personnel will attend pre-job safety briefings. A record of attendance will be documented and maintained by the Superintendent or his designee. A plan of the day (POD) meeting will be conducted daily to discuss the day's planned work activities, teview work hazards and controls, related safety topics and Lessons Learned. STARRT card reviews will be conducted at the work lacation prior to the start of a new task, when changed conditions warrant more frequent reviews.

\subsection{TRAINING DOCUMENTATION}

Training documentation for BJC personnel shall be maintained in the Local Educative Administrative Requirements Network (LEARN) database, and a hard copy file by the SSHR or designee. Training records for subcontractor and vendor (if applicable) personnel must be submitted to the SSHR or designee prior to the start of work. These records shall be maintained as part of the EMWMF operations files. 


\section{SITE-SPECIFIC PERSONAL PROTECTIVE EQUIPMENT}

Personal protoctive equipment requirements will be in accordance with BJC-EH-2005, Personal Protective Equipment and BJC-EH-2000, General Safety Requirements. EMWMF Management and Superintendents are responsible for ensuring the proper PPE is wom in accordance with the applicable work control documents and radiological work permit (RWP). The Site Safety and Health Representative (SSHR) or designee is responsible for ensuring the proper PPE is identified for the potential hazards to which workers may be exposed. The decision to downgrade or upgrade PPF shall be made by the SSHR or designee. Project Industrial Hygiene Lead or Field Radiological Eigincer, and in some situations shall require mutual agreement.

\subsection{EMWMF WORK CLOTHING REQUIREMENTS}

Basic clothing for EMWMF and subcontractor personnel for on-site work consists of full-length pants, sleeved shirt (sleeves at least 4 inches Iong), high visibility vest or shirt with reflective stripes, leather or task appropriate work gloves, safety-toed footwear (meeting ANSI Z41,1/ASTM F2413-05) or sturdy leather work boots depending upon where work is being performed. Tank tops, cut-off pants, shorts and tennis shoes are not permitted on the work site. Loose fitting clothes and jewelry will not be permitted near rotating machinery or equipment.

- Eye protection shatl, at a minimum, consist of safety glasses with fixed or firm clip-on affixed side shicids that meet the ANSI Z87.1standard. Prescription glasses wom as safety glasses shall also meet this requirement. ANSI compliant cover safety glasses used over ptescription glasses that do not meet the ANSI standard will be perrnitted. Safety glasses with rigid side shields shall be won at all times beyond the office/support trailer and parking lot areas. Face sbields shall not be wom in lien of safety glasses. Full-face protection shall be wotn when grinding, chipping, air or water blasting, etc.

- Foot Protection shall consist of sturdy leather or safely toed work shoes or boots that meet ANSI ZA1.1991/ASTM F2413-05. Safety toed shoes/boots are required for work performed in all industrial/construction work areas where there is potential for foot injuries due to falling or rolling objects, objects piercing the sole or where employee's feet are exposed to electrical hazards.

- Hard hats that meet ANSI Z89.I (Type 1) Class G as prescribed in 29 CFR 1910.135, Hecad Protection, are required for protection from fallitg or flying objects. Cowboy style hard hats and suspensions shall not be used. Hard hats shall be wom with the brim forward and the suspension properly installed. Hard hats shall not be damaged, painted, deformed, or marked in any way except. for markings required to identify the worker, company, craft, or title. Based on the scope of work, the Site Safety and Health Representative (or designee) may determine that in certain areas a hard hat is not required. Such an area will be clearly defined and boundaries communicated to site personnel. Areas designated as a "no hard hat required" zone, must have no potential for a head injury from impact, falling or flying objects, or from head contact with overhead objects, piping, etc. Hard hats shall not be required when riding within an enclosed vehicle or enclosed heavy equipment.

- Gloves All personnel performing work shall have leather work gloves in their possession at all times while in operating areas. Operating areas are those areas beyond the administrative offices (9983-GV and 9983-GU). Gloves shall be worn when handling materials or equipment unless such use will create an additional hazard. Gloves will be selected for use by the Site Satety and Health Representative (or designee). 
- High visibility safety vests or shirts with reflective stripes are required when walking/working neat or around mobile equipment or when deemed necessary by the Site Safety and Health Representative (or designee). The exception to this requirement is personnel engaged in hotwork who shall not wear safety vests while performing "cutting or welding" activities because of flammability concerns with the vests.

- Flame resistant (FR) clothing is required for all individuals invoived in hotwork activities. All hotwork activities shall be performed in accordance with BJC-EH-2007, Hot Work Work performed where there is potential for electrical arc flash shall be performed in accordance with BJC-EH-20\%9, Electrical Safery.

\subsection{PPE UPGRADE/DOWNGRADE AUTHORITY}

There are various circumstances under which it may be necessary to upgrade or downgrade PPE levels. Some examples are listed below:

\section{Reasons to upgrade:}

- Known or suspected presence of dermal hazards.

- Occurrence or likely occurrence of gas or vapor emission.

- Change in work or work environment that will increase contact or potential contact with hazardous or radioactive materials or a physical hazard.

- Request of the individual performing the task.

\section{Reasons to downgrade:}

- New information indicating that the situation is less hazardous than was originally thought.

- Change in site conditions that decrease the hazard.

- Change in work task that will reduce contact with hazardous materials.

These are only guidelines, not rules for upgrading or downgrading PPE. The decision to change PPE levels will be made based on job site conditions. All employees shall be made aware of the upgrade or downgrade.

\subsection{PPE DONNING/DOFFING GUIDELINES}

Workers will carefully don (dress) and doff (remove) PPE in the appropriate sequence. Improperly fitted protective clothing represents a severe potential hazaro and the appropriate size should be used. Where clothing is too small, worker movement is restricted, teas potential is increased, and the potential for worker fatigue is increased. Where clothing is too large, the possibility of a snag is increased and the dexterity and coordination of the wotker may be compromised.

The major objective of doffing PPE is to restrict the Itansfer of potential contamination from the work area. A secondary objective is for the worker doffing the garment and others in the area to a void conlact with contaminants on the outside of the garment. An appropriate decontamination setup. careful decontamination (as required), and cautious doffing will largely prevent such cross-contamination. 
Signs will be posted in radiological buffer areas or contamination reduction zones (CRZ) that will list the proper sequence for donning and doffing PPE. 


\section{INDUSTRIAL HYGIENE PROGRAM}

\subsection{EMWMF-SPECIFIC HAZARD COMMUNICATION}

EMWMF operations shall follow the BJC HAZCOM program, which complies with 29 CFR 1910.1200. The BJC program is described in BJCJOR-1745, Worker Safety and Heath Program, and in procedures BJC-EH-5140, Hazard Comtmunications, and BJC-EH-5I81, Hazardous Materials Information System. In accordance with the program, a monthly chemical inventory shall be submitted to the BJC HMIS manager. The Site Safety and Health Representative (SSHR), Projcet Industrial Hygiene Lead and line supervision are responsible for ensuring adherence to all the rules and regulations of this program, including ensuring that cmployees are aware of hazards associated with chemicals that may be used in the performance of their work, and that chemicals are properly stored, labeled, and placarded.

\subsection{INDUSTRIAL HYGIENE MONITORING AND SAMPLING}

The industrial hygiene monitoring and sampling requirements wilt vary by activity or task. Monitoring and sampling will be used to determine the effectiveness of engineering and admintstrative controls and to assess the effectiveness of PPE requirements. The waste streams that are disposed of at the EMWMF vary significantly and may include volatile organics, semi-volatile organics, metals, and inorganics. Although these constituents are present in very low concentrations, an industrial hygiene program is in place to understand the specific wastes and work activities performed.

The basis of the industrial hygiene monitoring and sampling is to evaluate baseline exposure level trends and subsequent periodic monitoring to verify baseline analytical results. Personnel exposure monitoring conducted to obtain a baseline involves sampling, at least $25 \%$ of the workers performing the activity or task (or a minimum of 2 employees), collecting a mininum of 10 samples (or fewer based on the duration of the work activity and approval of $\mathrm{BJC}$ lead industrial bygienist) to allow for statistical anslysis. Initially this montitoring will be conducted to establish a valid trend of wotker exposure levels. Waste fol characterization data will be used to identify those contaminants of concern that can subject workers to unacceptable levels of airtornte exposure. Industrial hygiene monitoritig for a specific work task may involve real-time monitoring, integrated exposure monitoring or both. Monitoring and sampling will be determined by the Project Industrial Hygiene Lead with input from the SSHR.

\subsubsection{Monitoring and Sampling Methods and Instrumentation}

Personal exposure monitoring/sampling will performed to evaluate the potential cxposure to individual employees and to ensure that the proper level of PPE has been selected for the task to which an employee is assigned. As each new lask with a polential for exposure is identificd, personal exposure samples will be collected to document exposure and evaluate the effectiveness of PPE that has been selected. Samples will be collected in the employee's breathing zone using personal sampling putnos and the appropriate collection media. Sampling shall be performed by qualified individuals in accordance with EH-5560. Workplace Industrial Hygiene Sampling. 


\subsubsection{Sampling Frequency}

Sampling frequencies for personnel exposure monitoring are shown in Table 1. Baseline sampling for persondel exposure is dependent upon the variety and duration of the tasks being performed.

Anomalous waste shipments: sampling may be required for constituents not listed in Table 1. Sampling and analyses shall be in accordance with NIOSH or OSHA methodology or approved equivalent.

\subsection{CHEMICAL HAZARDS/CONTAMINANTS}

\subsubsection{Slica, Crystalline (Quartz and Crystabalite)}

Waste lots received by the EMWMF frequently contain concrete from building demolition that can be the souree of airborne silica. Repeated over-exposure to silica can lead to chronic obstructive pulmonary disease (silicosis). According to NIOSH, while there may be a factor of individual susceptibility to a given exposure, the disease tends to occur after an exposure measured in years rather than months. Dust suppression methods used both at the generator sites and at EMWMF are effective for minimizing silica exposures.

\subsubsection{Heavy Metrls}

Wastes disposed of at the EMWMF normally contain various metals commonly used in building construction. Some of these metals can range from relatively innocuous to hazardous and have correspondingly higher or lower exposure limits. Target organs atd health effects are specific to the various metals. Some of the metals of greatest concen are lead, cadmium, chromium, and beryllium. Repeated over-exposures to these metals can affect the Jungs (e.g., beryllium sensitivity; berylliosis), skin and eyes, blood stream and kidneys. Some metals can affect the central nervous system (e,g-, lead and/or mereury). While these metals typically are not in a significantly dispersible form (they are bound in either a soil matrix or in debris), a program of routine monitoring shall be in place to ensure exposures remain well below the established limits. 


\subsection{Asbestos}

Various forms of friable and non-friable asbestos are received for disposal at the EMWMF. Exposure to asbestos can cause asbestosis and mesothelioma, a form of cancer. The waste acceptance critcria prescribe the method of waste receipt and disposal. Normally asbestos wastes ale received in double bags, wrappings, or containers. This material is also received from the generator after having been treated with a wetting agent.

Wastes received at EMWMF are routinely sampled and special sampling campaigns are initiated as needed for circumstances wherc new bascline information is needed.

\subsubsection{Total Dust}

Routine operations involving pushing and/or covering waste at the cell work face is a source of dusts that are not otherwise classified as toxic. Respiratory iltnesses can be the result of dust exposure depending on the particle size and concentratjons. Control measures such as dust suppression (usitig a hydroseeder) are routinely used. Total dust sampling ensures that the control methods used at EMWMF maintain potential exposures as low as possible.

\subsection{CONFINED SPACE MONI'TORING}

All monitoring associated with EMWMF operations confined space work activities will be performed 
Table 1. Sampling frequewcies for personnel exposure monitoring

\begin{tabular}{|c|c|c|c|c|}
\hline Sonrce. & Contaminant/Agent & Monitoring & Methodology & Frequency / Occurrence \\
\hline $\begin{array}{l}\text { Landfitl disposal of friable } \\
\text { and non-friable asbestos } \\
\text { contaminated construction } \\
\text { debris }\end{array}$ & Asbestos & $\begin{array}{l}\text { Breathimg zone samples and } \\
\text { area samples (as determined by } \\
\text { Project Industrial Hygienist) }\end{array}$ & $\begin{array}{l}\text { Personal sampling trains } \\
\text { Area monitoring }\end{array}$ & $\begin{array}{l}\text { Monthly after baseline (minimum of } 10 \\
\text { discreet samples) is extablished; then } \\
\text { monthly or as determined by Project } \\
\text { Industrial Hygiene Lead }\end{array}$ \\
\hline Confined spaces & $\begin{array}{l}\text { Oxygen deficiency, } \\
\text { Explnsive gases, } \\
\text { Hazardous gases }\end{array}$ & $\begin{array}{l}\text { Direct-reading instrumentations for } \\
\text { percent axygen, percent lower } \\
\text { explosive limit (LEL), hydrogen } \\
\text { solfide in patts per million (ppm), } \\
\text { and carbon monoxide in ppm. }\end{array}$ & Real-time instrumentation & $\begin{array}{l}\text { Prior to each entry, and as determined } \\
\text { by the Project Industrial Hygiene Lead }\end{array}$ \\
\hline Equipment and power tools & Noise & $\begin{array}{l}\text { Sound level meters andfor } \\
\text { Noise dosimetry }\end{array}$ & $\begin{array}{l}\text { Real-time instrumentationn } \\
\text { Data-logging }\end{array}$ & $\begin{array}{l}\text { Taskudriyen, as determined by the } \\
\text { Project Industrial Hygiene Lead }\end{array}$ \\
\hline $\begin{array}{l}\text { Hot environment andfor } \\
\text { Dress-out in impermeable or } \\
\text { semi-permeable clothing }\end{array}$ & Heal stress & $\begin{array}{l}\text { Environmenta! temperature or } \\
\text { Fulse rates or } \\
\text { Blood pressure or } \\
\text { Heat stress index }\end{array}$ & $\begin{array}{l}\text { Real-time instrumentation (WBGT) } \\
\text { Trained personnel } \\
\text { Trained personnel } \\
\text { Reference material }\end{array}$ & $\begin{array}{l}\text { Seasonal or task-driven, as determined } \\
\text { by the Project Industial Hygiege Lead }\end{array}$ \\
\hline Extreme winter conditions & Cold stress & $\begin{array}{l}\text { Weather thernometer and/or } \\
\text { Wind chill chart }\end{array}$ & $\begin{array}{l}\text { Visual readings } \\
\text { Reference material }\end{array}$ & $\begin{array}{l}\text { Seasonal or task-driven, as determined } \\
\text { by the Project Industrial Hygiene Lead }\end{array}$ \\
\hline $\begin{array}{l}\text { Covering waste materials } \\
\text { with soil }\end{array}$ & $\begin{array}{l}\text { Total dust } \\
\text { Respirable dust }\end{array}$ & Breathing zoяe samples & Persenal sampling trsins & $\begin{array}{l}\text { Monthly after baseline (minimum of } 10 \\
\text { disctcel samples) is established ; then } \\
\text { monthly or as determined by the Project } \\
\text { Industrial Hygiene Lead }\end{array}$ \\
\hline $\begin{array}{l}\text { Grouting equipment } \\
\text { designated for disposal }\end{array}$ & $\begin{array}{l}\text { Silica (Quarti and } \\
\text { cristobalite) }\end{array}$ & Breathing zone samples & Personal sampling trins & $\begin{array}{l}\text { Monthly after baseline (minimium of } 10 \\
\text { discreet samples) is established ; then } \\
\text { monthly or as determined by the Project } \\
\text { Hygiene Lead }\end{array}$ \\
\hline $\begin{array}{l}\text { Landfill disposal of } \\
\text { constnuction debris }\end{array}$ & $\begin{array}{l}\text { Heavy metals (such as } \\
\text { lead, chromium, } \\
\text { cadmium) }\end{array}$ & Breathing zone & Personal samphing trains & $\begin{array}{l}\text { Monthly after baseline (minimum of } \overline{0} \\
\text { discreet samples) is established; then } \\
\text { monthly or as determincd by the Project } \\
\text { Hygiente Lead }\end{array}$ \\
\hline $\begin{array}{l}\text { Landfril gases and } \\
\text { environmental sampling }\end{array}$ & Otgatnic vapers & Area samples & $\begin{array}{l}\text { Real-time instrumentation } \\
\text { (Photoionization (PID) detector } \\
\text { andifor Flame ionization (FII) } \\
\text { detector) }\end{array}$ & Quarterly (environmental sampling) \\
\hline $\begin{array}{l}\text { Miscellaneous sampling } \\
\text { during maintenance } \\
\text { activities }\end{array}$ & $\begin{array}{l}\text { Heavy metals, organic } \\
\text { yaposs }\end{array}$ & $\begin{array}{l}\text { Breathing zone samples and area } \\
\text { samples }\end{array}$ & $\begin{array}{l}\text { Real-time instrumentation, personal } \\
\text { sampling }\end{array}$ & $\begin{array}{l}\text { As determined by the P'oject Industrial } \\
\text { Hygiene Lead }\end{array}$ \\
\hline
\end{tabular}




\section{CONTROLS FOR PHYSICAL AND OPERATIONS PROCESS HAZARDS}

\subsection{GENERAL SITE SAFETY}

Achievement of "Zero Accidejt Performance" can be attained through the use of safe work practices and hazard controls. The guidelines listed below are provided to assist personnel in making informed decisions regarding the manner in which work is perfomed. Additional requirements are contained in BJC-EH-2000, General Safery Requirementr.

- Personnel will be held accountable for understanding and complying with BJC.FS-1001, Work Control Process.

- Horseplay or fighting is prohibited.

- Eating, drinking, smoking, chewing gum, using tobacco, or any other hands-to-face activities are prohibited on the site except in designated areas after face and hands have been washed.

- When required to sit or kneel on the ground, avoid contaminated surfaces.

- A void piacing tools or equipment on contaminated surfaces.

- Mobile and temporary facilities (trailers, storage sheds, etc) shall be properly grounded and anchored with Access/Egress routes established, and contain required fire protection extinguishers.

- Bringing defective or unsafe equipment onto the site is ptohibited.

- Only authorized employses may enter the work areas. Work areas shall be barricaded with the appropriate material and signage. Stepping over or ducking under barricades is prohibited. Barricades shall be maintained at all times while in use.

- Hazard assessment is a continuous process. Personnel must be aware of their surroundings and constantly be aware of the chemical and physical bazards that are or may be present.

- The location of overhead power lines and underground utilities must be established prior to excavation/penetration activities and heavy equipment operation.

- Detection or appearance of unusual liquids, odors, or discolored soil could indicate the presence of contamination and should be reported to the Cell Operations or Maintenance and Facilities Superintendents and the Sile Safety and Health Representative (SSHR) immediately.

- Personel are to report any other unusual or potentially hazardous conditions to their immediate supervisor and the SSHR for investigation and/or corrective action.

\subsubsection{Buddy System}

The buddy system is to be used, to the extent practicable, while performing EMWMF operations aclivities In addition, personnel entering the contact water pond area are required to notify site RCTs prior to entry and must either have a "buddy" present or wear a U.S. Coast Guard approved flotation device (life vest). 
When working nearfaround the sediment basin personnel are required to implement the buddy system. A two-way radio is to be carried while performing work at the EMWMF site.

\subsubsection{Slips, Trips and Falls}

A vatitty of walking/working surfaces exist at the EMWMF site e.g., soil, gravel, grass, and compacted waste. These surfaces may be flat, slightly or steeply sloped, wet and potentially slippery that create an abundance of slip, trip, and fall hazatds. Operations personnel wear sturdy leather shoes or safety toed boots (depending upon work pertormed) and must take care to ensure good footing. Clear paths of ingresslegress are created and maintained to every worksiation and shall be used by all personnel. Personnel should be aware of changes in walking/working surfaces, e.g., gravel to soil or grass, dry to wet, etc. Walking surfaces in the parking arcas are gravel covered and may be unlevel in some locations thercfore personnel entering/exiting the office trailers should exercise caution when watking in these areas to avoid slips, trips and falls.

Roadways, access ways, aisles, stairways, scaffolds, and ladders, shall be kept chean and clear of hoses, extension cords, welding leads, and other obstructions that may cause tripping or other accident hazards.

\subsubsection{Housekeeping}

As standard practice, good housekeeping will be strictly enforced. All material, scrap, tools, tonlboxes, and other equipment will be stored in a neat and orderly fashion. Trash and serap should be removed from the work area on a regular basis (i.e., at least daily, before leaving the work area for the day) and shall not accumulate, especially in walkways, tnder stairs, at the bases and landings of stairs and ladders, and near flammable substances.

- Litter - No discarded material shall be stored an-site for periods longer than one month. All discarded materials shall be disposed of properly in dumpsters marked for sanitary waste only.

- Areas identified for refueling operations shall be maintained clear of obstructions and shall be properly designated.

The requirements listed above shall be implemented and apply to sanitary solid waste generated during EMWMF operations activities.

Any wastc materials that may have blown out of the waste cell shall be returned to the cell for appropriate burial.

\subsubsection{Jlumination}

Adequate illumination intensity shall be provided in all active work areas and access ways in accordance with OSHA Standard 29 CFR 1926.56. Emergency lighting, where required, shall be tested and maintained per NFPA 101. Chapter 7 . In general a minimum of 5 foot candles of lighting is required in all active work areas. 


\subsubsection{Signs and Barricades}

All signs shall be properly colored and contain the required information as prescribed by OSHA standards.

- Signs shall be visible from a distance of $15 \mathrm{ft}$. Signs waming of specific hazards or hazardous work areas shall be posted to warn personnel of potential personal hazards where they are working (ex., high noise levels, moving vehicles, radiological, hazardous waste exclusion zone. atc.).

- Signs shall be constructed of metal, fiberglass or plastic and shall be promptly removed when no longer needed.

- Danger tags will be placed on devices/equipment that is unsafe to use.

- Tagged equipment shall not be used until the equipment/device has boen repaired and it has been determined that repaired equipment/device is safe to operate.

- Signs shall also be conspicuously placed in conjunction with barricades. No minimum spacing is required unless otherwise specified in OSHA 29 CFR 1926 Subpart G.

The types of barricades permitted on the project include rope, tape, and hard barricades.

- The color of the barricades shall comply with OSHA requirements. If hazard information is not printed on barricades, then signs or tags shall be attached. DOE radiological color classifications shall be used for radiological barricades. Rope, tape, chain, and similar barriers used to designate the boundaries of posted radiological areas shall be yeliow and magenta.

- Stepping over or ducking under barricades is prohibited. Barricades shail be maintained al all times while in use.

Guardrails and other fall-protection systems shall be constnucted in accordance with $29 \mathrm{CFR} 1926$ Subpart M requirements. BJC-EH-2006, Fall Prevention and Protection shall be used for all work performed where fall-protection systems are required.

\subsubsection{Noise}

The operation of equipment during EMWMF waste disposal operations can create areas where noise levels exceed 85 decibels on the A-weighted scale (dBA). Exposure to excessive noise levels may lead to. temporary or permanent hearing loss. All noise level monitoring and posting shall be performed in accordance with 29 CFR 1910, Occupational Noise Exposure and Hearing Conservation Program. Feating protection shall be wom by EMWMF operations and subcontractor personnel where noise levels are suspected or shown by noise level meter monitoring to exceed $85 \mathrm{dBA}$. In the event that a new noise hazard, such as a new piece of equipment, is brought onsite, the Site Safety and Health Representative (SSHR) will coordinate with the Project Industrial Hygiene Lead to test the equipment or area for possible hazards.

\subsubsection{Biological Hazards}

Biological hazard refers to plants, animals, or their products that may present a potential risk to the health and well-being of humans. Operations at the EMWMF require working outdoors to perform waste disposal, pumping of contact water and leachate to collection ponds, storage tanks or transfer to tankers 
for transport offsite to a treatment and disposal facility. Personnel working outdoors may come in contact with stinging and biting insects (wasps, bees, and mosquitoes), bird droppings, poisonous plants (poison ivy. poison oak), and venomous snakes and spiders. Proper identification of these hazards and avoidance whenever possible is the hest prevention. Also, various barrier creams have shown positive results in preventing contact dermatitis from plants. Sprays and repellents can be used for itsect control. Personnel with known allergies to insect stings shall inform the SSHR.

\subsubsection{Seqere Weather}

Severe weather conditions may include, but are not limited to, a severe thunderstom warning, tornado waming, the approach/duration of an electrical storm, and weather extremes such as wind speeds greater thar 34 mph. The SSHR (or designee) or supervision will terminate outdoor operations because of weather conditions and shall authorize re-start after the severe weather passes. Outdoor operations shall be suspended when the following occurs:

- A lightning notification is received from tise ETTP PS\$ via pager

- Lightning flashes are observed in the vicinity of the EWMMF

- A tomado warning has been issued by the National Weather Service or the ETTP PSS for the vicinity of EMWMF

Persontiel will evacuate outdoor work areas to the office trailers or an appropriate offsite location until the all clear is given and work can be resumed. Work may not resume until 30 minutes after the last visibly observed lightning.

In the event a tornado waming is issued personnel will evacuate to areas identified in BJC/OR-27]4, EMWMF Emergency Response and Contingency Plan.

Severe weather bulletins such as severe thunderstorm and/or tomado watches issued by the National Weather Service or ETTP PSS will be evaluated by the SSHR (or designee) and supervision and a determination made regarding outside operations.

If the wind speed exceeds $34 \mathrm{mph}$ or 3 wind gusts exceed 34 mph in any 15 minute period operations shal 1 be temposarily suspended and personnet removed from the work area to the office/support trailers. When wind speed reduces below 34 mph work may resume after the SSHR (or designee), supervision and a craft representative have inspected the work areas and determined them to be safe.

The SSHR or designee will provide formal guidasce regarding weather related questions and or concetns based on visual observation, radar observation, radio warning, and notifications received from the PSS.

\subsubsection{Temperature Extremes}

BJC-EH-5136, Temperature Extremes, hear stress and cold stress prevention programs shall be implemenled during periods of extreme temperatures. Working in protective clothing can greatly increase the likelihood of heat fatigue, heat exhaustion, and heat stroke, the latter being a life-threatening condition. Personnel will be reminded to monitor co-workers and themselves for adverse effects and that they may take breaks as needed. If employees are dressed out in protective clothing and temperatures at the work site are above $80^{\circ} \mathrm{F}$, the wet bulb globe temperature (WBGT) shall be monitored by the SSHR or designee to assess the potential for heat stress. During periods of bot weather or when workers may be affected by heat stress, the line supervision shall provide cool down areas and ensure ready access to an 
adequate supply of cool drinking water andfor electrolyte replenishing drink such as Powerade ${ }^{\mathrm{M}}{ }^{1}$. The SSHR or designee shall be responsible tor briefing workers on the signs of heat stress when temperature conditions require it. This may be done during the daily safety or plan-of-the-day brieting. Work/rest schedules shall be implemented, when necessary, within the guidelines of the American Conference of Governmental Industrial Hygienists (ACGIH), WBGT threshold limit valuesß (TLVs).' and the National institute for Occupational Safety and Heaith (NIOSH).

For cold stress prevention, line supervision shall ensure that personnel use properly insulated clothing for the head, hands, feet, and body. During cold weather periods, heated break areas shall be available.

\subsubsection{Sanilation}

Potable water containers and portable toilets shall comply with OSHA $29 C F R$ 1910.]41 requirements. Single-use cup dispensers and waste containers will be provided adjacent to all portable water dispensers. Water shall not be dipped from containers. Water dispensers shall be clearly identified as drinking water. Water dispensers in use shall be cleaned daily. Break areas shall be kept clean. Trash receptacles shall be stationed in all eating areas and emptied frequently.

\subsection{MOTOR VEHICLES AND HEAVY EQUIPMENT}

Equipment operators and personnel in areas where hesvy equipment operates follow guidance for safe operation and responsibilities established in EMWMF work control documents such as work packages, procedures, and plans. Procedures used by EMWMF operations personsel that address safe operation include EMWMF-OP-003, Waste Placement, EMWMF-OP-008, On-Site Staging, and EMWMF-0P-012, Equipment Decontomination, and BJC-FS-1039, Construction Equipment Inspection and Maintenance Program.

\subsection{LOCKOUTTAGOUT}

EMWMF operations and subcontractor persongel shall comply with the requirements of BJC-EH-2002, Hazardous Energy Control (Lockout/Tagout) when performing tasks requiring lockoutitagout (LOTTO). Site-specilic guidance from the procedure includes the following:

- Identification of the LOrTO lssuing Authority, supervisor and effected employees:

- Only personnel trained in LO/TO are apthorized to perform equipment inspection, maintenance, or servicing tasks requiring the use of LOTTO.

\subsection{ELECTRICAL SAFETY}

- Identification, control and/or avoidance of overhead and underground utilities that maybe encountered during the work, including how identification of energized utilities shall be coordinaled with othet DOE prime Contractors;

\footnotetext{
' Reference herein to any specific commercial product, process, or service by trade name. tradenark, manufacturer, or otherwise, does tot necessarily constitute or imply its endorsement, recommendation. or favoring by the United States Government or any agency thereof or its contractors or subcontractors.
} 
- Procedures for implementation of the sections of the National Electric Codes (NEC), and OSHA requirements applicable to any electrical work that will be performed.

- All electrical work shall be performed in accordance with BJC-EH-2009, Electrical Safety.

\subsection{FALL PROTECTION}

The requirenents of BJC-EH-2006, Fall Prevention and Profection shail apply when the distance from working or walking surface to grade or lower level is 6 feet or more for construction activities or 4 feet or more for operations activities (possibly less if other lower level hazards are present).

\subsection{HOTWORK}

All EMWMF welding/burning/hot work will be performed in accordance with the requirements found in BJC-EH-2007, Hot Work.

\subsection{WORKING FROM LADDERS}

EMWMF aperations activities require frequent use of portable ladders. This primarily includes the use of step-Jadders, extension ladders, and straight ladders. All ladder and scaffold use, inspection, and training activities at EMWMF will comply with BJC-FS-1015. Scaffolds and Ponable Ladders.

\subsection{FIRE PREVENTION}

Proper housekeeping and storage techniques shall be used to keep all potential sources of ignition away from combustible/flamnable materials. Managers, supervisors, and the SSHR are responsible for conducting work site inspections that include observations of compliance with the fite safety requirements. These inspections shall include observations of work-site safety and housekeeping issues and shall specifically address proper storage of chemicals and supplies, unobstructed access to fire extinguishers, and emergency evacuation routes. Good housekeeping requirements to minimize combustible "fuel" sources include:

- Oily rags, cleaning rags-To prevent fires from spontaneous combustion, oily rags only shall be stored in metal containers with tight fitting metal lids. Excessive amounts of "oily rags" shall not be allowed to accumulate.

- Combustible Waste-Combustible waste materials shall not be accumulated on-site for periods greater than one month.

The following safe work practices will be used to protec against fures:

- All office trailers and Boundary Control Stations will be equipped with a fire extinguisher of not less than 10: B units or higher.

- At least one portable fire extinguisher having a rating of not less than 20: B units will be located at each work area (refer to BJC-FP-2006, BJC Progmm for Controlling Combustibles and ignition Sources). 
- Each piece of heavy equipment on-site shall be equipped with at least one dry chemical or carbon dioxide fire extinguisher, having a minimum Underwriters Laboratory (UL) rating of 5.B.C. The pin shall be in place and proper operating pressure maintained.

\subsection{TOOL SAFETY}

Use of improper or defective tools can contribute significantly to the occurrence of accidents on-site. Tool safecy requirements listed in BJC-EH-2000, Generat Safery Requirements and the individual tool manufaclurer's requirements shall be implemented. All tools shall be maintained in good condition. property stored, and used for their intended purpose only in accordance with the manufacturer's tequirements manual and applicable OSHA standards including 29 CFR 1910. Subpart P, and 29 CFR 1926, Subpart I.

\subsection{CONFINED SPACE ENTRY}

All EMWMF confined space work activities shall be performed in accordance with the requirements found in BJC-EH-5138, Confined Space Program Description.

\subsection{MATERIAL HANDLING AND STORAGE}

Walkways and aisles shall be kept clear at all times, and layoown areas shall he neat and orderly. Walkways shall have a 3-foot aisle that shall remain clear at all times. Material shall be stored on level ground, and the boundaries of laydown areas shall be identified. Material shall not be stored within $6 \mathrm{ft}$ of hoistways or floor openings. Poles, pipe, and other stock that may roll shall be wedged to prevent spreading and rolling.

All new material shall be stored on dunnage (off the ground) and secured as necessary to prevent blowing, falling. sliding, or colkpsing. Debris and scrap material need not be stored on dunnage if the matcrial is not to twe moved with rigging and can be maintained in a stable manner. Nails shall be removed from lumber that is to be le-used. Nails in scrap lumber that will not be re-usect shall be bent back No material, tooks, or equipment shall be leaned against ather objects or walls unfess they are secured from movement.

Chemicals shall be stored observing proper storage requirements listed on the MSDSs. Incompatible chemicals shall not be stored together. Personel shall ensure that storage containers and ancillary equipment are constructed of materials that are chemically compatible with the product/chemical to be transferred from the original containers.

\subsection{HOISTING AND RIGGING}

All hoisting and rigging activities (i.c., use of overhead and gantry cranes, mobile cratnes, dericks, hoist, rigging devices, forklift tucks, and devices such as wire rope, chain, metal mesh slings, synthetic-web slings, and special below-1he-hook attachments and fixtures) shall be conducted in accordance with BJC-FS-1008, Hoisting and Rigging, BJC-FS-1009. Qualification and Performance as Competens Person Rigger, and BJC-FS-1037, Hoisting and Rigging Hardware Inspection and Testing. 


\subsection{EXCAVATION AND TRENCHING}

The requirements of BJC-FS-1004, Excavation/Penetration will be followed at the EMWMF. In addition, applicable 29 CFR 1926 Subpart $\mathrm{P}$, "Excavations" requirements shall be implemented to protect EMWMF operations personnel who work in or around excavations/trenches, penetrations into the carth surface, concrete, or pavement, and interior surface penetrations in building walls, floors, and ceilings. An Excavation/Penetration Permit wili be obtained for all excavation/penetration activities except for those exempted activities listed in the procedure.

\subsection{EMERGENCY EYE WASH AND PERSONNEL DECONTAMINATION SHOWER}

The SSHR (or designee) will determine which tasks offer a reasonable polential for employee eye injury. Eye wash bottlcs are available in the Boundary Control Stations in the disposal cell area (Limitcd Area) and an emergency eye wash station capable of providing a drenching capability of 0.4 gallons per minute for at least 15 minutes is locuted in Building 9983-GU. Emergency drench units shall be inspected weekly and the inspection documented.

\subsection{FIRST AID KITS AND SUPPLIES}

First aid kits, for use by trained personnel, are located in the office and break trailers (9983-GV and 9983-GU) and in the Boundary Control Stations in the Limited Area. Trained personnel at EMWMF are the SSHR (or designee), Cell Operations Superintendent, and the Maintenance and Facilities Superintendent. These individuals shall have current first aid and cardiopulmonary resuscitation (CPR) training as well as Bloodbome Pathogen training. Kits may be placed at other locations (approved by the SSHR) to provide support for minor injuries by trained personncl or for use while waiting for emergency response. First aid kits shall, at a minimum, meet the requirements of ANSI Z308.1. First aid kits shall be inspected weekly by the SSHR (or designee) and replenished as necessary. A log of all first aid kit use shall be maintained and submitted to the BJC Safety Manager monthly.

\subsection{ASBESTOS AND MAN-MADE FLBERS}

All work involving asbestos is to be performed in accordance with BJC-EH-5177, Asbestos and Other Fibrous Materials and BJC/OR-J745, Worker Safery and Health Program. Activities involving the disposal of friable, respirable, or uncharacterized fibrous glass and other synthetic (man-made) vitreous fibers, which may reasonably be expected to exceed airbome concentrations at or above established Occupational Exposure Limits shall require implementation of appropriate safe work practices and controls. 


\section{RADIOLOGICAL PROTECTION}

EMMWF operations personnel shall comply with BJC-EH-4000, Radiation Protection Program Description. Activilies will be performed under approved RWPs. The Field Radiological Engineer (FRE) will ptovide direction on radiological issues. The FRE will coordinate with other safety and health

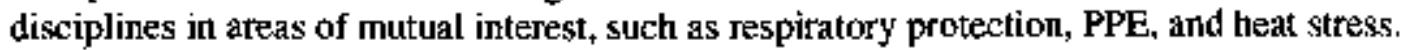




\section{ENVIRONMENTAL COMPLIANCE}

EMWMF operations shall comply with BJC/OR-1747, Environmental Compliance and Protection Program Description. The Environmental Compliance and Protection (EC\&P) Lead will provide direction on environnental issues.

All operations activities performed at the EMWMF are designed to prevent the release of pollutants into the environment and to comply with regulatory guidelines as presented in BJC/OR-2711, Environmental Compliance Ptan (ECP). Contaminated substances are to remain within the EMWMF unless released and transported from the site under strictly controlled conditions. Operating controls minimize the release of pollutants to air by dust control management, to surface water by preventing surface water access to the EMWMF and with stormwater controls, and to groundwater by the design and operation of a liner and leachate collection system. Environmental monitoring of air, surface water, stormwater, and groundwater is performed during operations on a regular basis to ensure the containment of contaminants generated or potentially released during operations of the EMWMF. 


\section{SITE COMMUNICATIONS}

Primary forms of site communications used during EMWMF operations activities include: two-way radio, the Y-12 plant telephone system, and cellular telephone.

\subsection{TWO-WAY RADIOS}

EMWMF operations personncl shall use two-way radios as a primary means of site communications. Radio checks shall be performed routincly to ensure that radios are functioning properly. Radio comnunications will be in accordance with BJC-FS-1031, Communications.

\subsection{DEPARTMENT OF ENERGY (DOE) TELEPHONE SYSTEM}

Hard line telephone communications at the EMWMF site are part of the DOE telephone system. The nearest hard line telephone communications to the EMWMF active waste disposal cell area are located in Buildings $9983-\mathrm{GV}$ and $-\mathrm{GU}$. These hard line telephones will be used for dialing 911 in the event of a site emergency.

\subsection{CELLULAR TELEPHONES}

Cellular telephones should not be used when operating equipment or motor vehicles at the EMWMF site. In case of an emergency, personinel shall dial the PSS' seven-digil telephone number (Y-12: 574-7172 and ETTP 574-3282), and not 9! I if calling from a cellular telephone. 


\section{NOTIFICATION AND REPORTING}

Personnel shall immediately notify the Site Safety and Health Representative (SSHR) or designee and their inmediate supervisor of all occupational injuries/illnesses. In case of an emergency involving personal injury or illness, a designated first aid and CPR responder will render immediate first aid. Additional emergency medical services may be summoned if deemed necessary based upon the severity of the injury of illness. The B\&W Y-12 and ETTP Park Shift Superintendent (PSS) will be contacted at 574-7172 or 574-3282, respectively.

\subsection{MEDICAL ILLNESS/NJURY}

The SSHR, safety support personnel and the field superintendents at EMWMF have current first aid and cardiopulmonary resuscitation (CPR) training. Because of the potential for occupational exposure to potential pathogenic bodily fluids and tissue, ptoviders of first aid and CPR stall receive Bloodborne Pathogen Training as specified in 29 CFR 1910.1030 and have the opportunity to receive, free of cost, Hepatitis-B vaccinations (HBV).

Employees requiring medical treatment (e.g., minor first aid treatment) for non-seriaus or non-life threatening injuries or illnesses shall be taken to one of the medical facilities indicated below in Table 2 for treatment. Employees with mintor injuries shal] not be allowed to drive themselves to receive medical attention. An EMWMF supervisor shall drive the employee with minor injuries/illnesses to a medical provider.

NOTE: ETTP Health Services is the first choice for employees to receive medical attention beyond first aid depending on the severity of the injury or illness and the time of day.

Table 2. Non-Emergency T'reatment I acatlons

\begin{tabular}{l|l}
\hline ETTP Health Services (K-25 Medical) & Methodist Medical Center of Oak Ridge \\
\hline Building K-1007 & 990 Oak Ridge Tumpike \\
Highway 58 & Oak Ridge, TN 3783 L-2529 \\
Oak Ridge, TN 3783 1 & $(865) 835$-1000 Main Switchboard \\
(865) $574-8562$ & (865) $835-4908$ Emergency Department \\
Office Hrs.: 7:30 a.m. -4:00 p.m. & (NOTE: for after hours/off shift work only) \\
\hline
\end{tabular}

In case of an illness or injury, the SSHR, with assistance of the field superintendents, will evaluate the nature of the illness/injury. The affected worker should be decontaminated to the extent possible, if required. All non-emergency wotk-related injuries will be treated by BJC Health Services at ETTP. When a worker sustains a minor injury, the SSHR or designee shall immediately notify the BJC Health Services (574-8562) if the injury occurs during weekday hours of 7:30-4:00, or the ETTP PSS (574-3282) during off-hours. Key Personnel Emergency Contact Names and Numbers are posted at all building exits, provided on laminaled cards following completion of EMWMF Site Access Orientation, in Building/Facility Energency Plans (orange books) and an up-to-date listing will be maintained and posted in the Boundary Control Stations in the Limited Area. Emergency response for serions injuries or illoesses shall be through the immediate notification to the Y-12 and ETTP PSS offices. 


\subsection{ACCIDENT/INCIDENT REPORTING AND RECORDKEEPING}

The SSHR and line supervision shall be notified immediatcly in the event that a work-related injury or illness occurs for operations personnel or subcontractor employees, vendors, or visitors. Line supervision in conjunction with the SSHR (or designee), will investigate and report each accident or incident involving work-related injury or illness, or damage to govemment vehicles and property. Requirements of BJC-EH-2001, Accident/hrident Reporting, will be followed. 


\section{EMERGENCY RESPONSE}

BJC/OR-2714, Environmental Management Waste Management (EWMF) Emergency Response and Contingency Plan contains detailed descriptions of emergency response actions to be taken at EMWMF. A brief summary of some emergency response actions are contained in the sections below.

\subsection{EMPLOYEE RESPONSIBILITIES}

The minimum requirements of EMWMF employees during an emergency are to know the following about his or her work area:

- Jocation of site emergency exil routes.

- location of the facility assembly point(s).

- location of the nearest fire extinguisher. Fire extinguishers should only be used by personnel who know how to operate them safely, in addition to knowing the type of fire (e.g., electrical petroleum product, wood) and the appropriate type of fire extinguisher to be used under the existing conditions.

- location of ather emergency equipmeft such as the eye wash station.

- location of the nearest telephone or other means of communication such as radio or cellular telephone and emergency contact list.

\subsection{REPORTING AN EMERGENCY}

Upon discovering an emergency situation, an employee must immediately take action to initiate emergency response activities. This action involves first removing himself/herself from immediate danger and notifying the Site Safety and Health Representative (SSHR) and site Superintendents. The SSHR shall initiate site emergency response and contingency plan actions (in accordance with BJC/OR-2714, Emergency Response and Contingency Plan) immediately upon notification by contacting both the Y-12 and ETTP PSS of the emergency situation so that the emergency response system can be activaled. Y-12 emergency response personnel will provide "first responder ${ }^{+1}$ services until such time that ETTP emergency response personnel artive at EMWMF.

\subsection{FVACUATION ROUTES}

Maps of EMWMF evacuation routes are posted in the office and employee break trailers, in the Building/Facility Emergency Plan binders (orange books), and are included in this HASP as Fig. 2. 


\subsection{ASSEMBLY POINT(S)}

The primary assembly point at EMWMF is Assembly Station Number 23 located immediately east of the driveway that encircles the office trailer (Blog. 9983-GV) and the nottheast corner of the building.

A secondary assembly point is located immediately notth of Bldg. $9983-\mathrm{GV}$ at the gravel entrance to the material laydown area.

EMWMF site sign in rosters will be used for accountability in the event of a site emergency requiring evacuation to the assembly point (or shelter in place). 


\section{REFERENCES}

BJC-EH-1015. Scaffolds and Portable Ladders, Bechtel Jacobs Company LLC, Oak Ridge. TN.

BJC-EH-2000. General Safery Requirements, Bechtel Jacobs Company LLC, Oak Ridge, TN.

BJC-EH-2001, Accident/ncident Reporing, Bechtel Jacobs Company LLC, Oak Ridge. TN.

BJC-EH-2002, Hazardous Energy Control (Lockout/Tagout). Bechtel Jacobs Company LLC, Oak Ridge, TN.

BJC-EH-2005, Personal Protective Equipment, Bechtel Jacobs Company LLC, Oak Ridge. TN,

BJC-EH-2006, Fall Prevention and Protection, Bechtel Jacobs Company LLC, Oak Ridge, TN,

BJC-EH-2007, Hot Work, Bechtel Jacobs Company LLC, Oak Ridge, TN.

BJC-EH-2009, Electrical Safety, Bechtel Jacabs Company LLC, Oak Ridge. TN.

BJC-EH-2010, Hazard Assessment. Bechtel Jacobs Company LLC. Oak Ridge, TN.

BjC-EH-4000, Radiation Protertion Program Description for Bechtel Jacobs Company LLC. Oak Ridge, Tennessee, Bechtel Jacobs Company LLC, Oak Ridge, TN.

BJC-EH.512], Occupational Noise Exposure and Hearing Conservation Program, Bechtel Jacobs Company LLC, Dak Ridge, TN.

BJC-EH-5138, Confinted Space Program Description, Bechtel Jacobs Company LLC, Oak Ridge, TN.

BJC-EH-5 140, Hazard Communications, Bechtel Jacobs Company LLC, Oak Ridge, TN.

BJC-EH-5151, Respiralory Protection Program. Bechlel Jacobs Company LLC, Oak Rjdge, TN,

BJC-EH-5177, Asbestar and Other Fibrous Materiats, Bechtel Jacobs Company LLC, Oak Ridge, TN.

BJC-EH-5181, Hazardous Materials Information System, Bechtel Jacobs Company LLC, Oak Ridge. TN.

BJC-FS-1031, Communications, Bechtel Jacobs Company LLC, Oak Ridge, TN.

BJC-EH-5121, Occupational Noise Exposure and Hearing Conservation Program, Bechtel Jacobs Company LLC, Oak Ridge, TN.

BJC-EH-5140, Hotard Communications, Bechtel Jacobs Company LLC, Oak Ridge, TN.

BJC-EH-5138, Confined Space Program Description, Bechtel Jacobs Company LLC. Oak Ridge. TN. 
BJC-FS-1001, Work Consol Process, Bechtel Jacobs Company LLC, Oak Ridge, TN.

BJC-FS-1004, Excavation/Penetration Pemit, Bechtel Jacobs Company LLC, Oak Ridge, TN.

BJC-FS-1008, Hoisting and Rigging, Bechtel Jacobs Company LLC, Oak Ridge, TN.

BJC-FS-1009, Qualification and Performance as Competent Person Rigger, Bechtel Jacobs Company LLC., Oak Ridge, TN.

BJC-FS-1031, Communicurions, Bechtel Jacobs Company LLC, Oak Ridge, TN.

BJC-FS-1037, Hoisting and Rigging Hardware Mrpection and Testing, Bechtel Jacobs Company LLC, Oak Ridge, TN.

BJC-FS-1039, Construction Equipment Inspecrion and Maintenance Program, Bechtel Jacobs Company LLC, Oak Ridge, TN.

BJC-GM-1400, Integrated Safery Management System Description, Bechtel Jacobs Company LLC, Oak Ridge, TN.

BIC/OR-1745, Worker Safety and Health Program. Bechtel Jacobs Company LLC, Oak Ridge. TN.

BJC/OR-1747, Environmental Compliance and Protection Program Description, Bechtel Jacobs Company LLC, Oak Ridge. TN.

BJCJOR-2711, Environmental Compliance Plan, Bechtel Jacobs Company LLC, Oak Ridge, TN.

BJCFOR-27J3, EMWMF Operations Plan, Bechtel Jacobs Company LLC. Oak Ridge, TN.

BJC/OR-2714, EMWMF Emergency Response and Contingency Plan, Bechtel Jacobs Company LLC, Oak Ridge, TN.

EMWMF-OP-003, Waste Placemert, Bechtel Jacobs Company LLC, Oak Ridge, TN.

EMWMF-OPn008, On-Site Staging, Bechtel Jacobs Company LLC, Oak Ridge, TN.

EMWMF-OP-012, Equipment Decontamination. Bechtel Jacabs Company LLC, Oak Ridge, TN. 
THIS PAGE LEFT BLANK INTENTIONALLY 
BJC/OR-2715/R2

\section{RECORD COPY DISTRIBUTION}

File--EMEF DMC-RC 